\title{
Design and Development of Aonla Pricking Machine
}

\author{
Singh Raj Vijay ${ }^{1 *}$, Moses, S.C. ${ }^{2}$, Singh Vijeta ${ }^{3}$ and R.N. Alam
}

Farm Machinery and Power Engineering, SHUATS, VIAET, Prayagraj, Allahabad, Uttar Pradesh, India

*Corresponding author: vijayrajsingh799@gmail.com (ORCID ID: 0000-0002-6358-5224)

Paper No. 797

Received: 08-07-2019

Revised: 09-10-2019

Accepted: 22-11-2019

\begin{abstract}
Aonla has the hallowed position in Ayurveda. Aonla is native to India and also grows at tropical and subtropical region like India, Pakistan Sri Lanka and Uzbekistan. In India Uttar Pradesh has the highest area under cultivation and production of Aonla. Area under Aonla orchard in Pratapgarh district of Uttar Pradesh is about 13000 hectares (Nitin Kumar et al.). Aonla is mostly used in making murabba, pickles and candy etc. Traditional method for making Aonla murabba is hygienic because for making murabba, Aonla has to be pricked first and that pricking method of Aonla is drudgery prone and most of the workers are injured by hand pricking method Also it takes too much time for pricking (Ganvir et al.). Till now Aonla is pricked by hand and power operated machine. Hand pricking of Aonla causes injury to the hands of the farm women and is a tiresome and slow process with low output capacity whereas the power operated machines are very costly and out of reach of medium and small farmers. Thus, to overcome these problems and keeping in mind the benefits of small and medium farmers a low cost, pedal operated aonla pricking machine suitable for farm women has been developed in the Department of Farm Machinery and Power Engineering, SHUATS, Allahabad. This machine is paddle operated with an output capacity of 3-3.5 q/h. No injury is caused to the farm women operating the machine. However the machinen can be operated both by farm women as well as men farmers. Hopper of machine is containing 66 no. of Aonla at a time. Floor area used by this machine is $80 \times 80 \mathrm{~cm}$. Pricking needles, sieve plate and fruit plate used in this machine is made of stainless steel because of corrosion. Needles used in this machine are of 2 inches. 756 no. of needles are used in this machine. Maximum depth of pricking in Aonla is $7 \mathrm{~mm}$ and max.dia of needle is $8 \mathrm{~mm}$. This machine is efficient for small and medium farmers

\section{Highlights}

( Aonla pricking machine was developed for small and medium farmers. This machine was used for pricking Aonla. This machine has capacity to prick 3-3.5 qt Aonla in a hour which is too good in comparison to hand pricking. It has high in capacity and negligible in human drudgery.
\end{abstract}

Keywords: Aonla, drudgery, Ayurveda, pickles, murabba

Aonla has a hallowed position in Ayurveda. Aonla is also known as (Phyllanthus emblica) or Indian gooseberry. Aonla is native to India Uttar Pradesh has the highest area under cultivation and production of Aonla in India. Aonla has been used for making murabba, pickles, candy and many more products (Ghuge et al.) Aonla murabba is an Ayurvedic medicine and Indian recipe used for gastric problems and as general health tonic. It is rich in Vitamin c and other essential nutrients and antioxidants (Goyal et al.). The fruit of Aonla has average diameter of $38.8040 .96 \mathrm{~mm}$ (vertical) and
33.28 to 34.81 (horizontal). Average weight whole fruit, seed and pulp are 31.80 to 37.76 g respectively. Specific volume and specific gravity of fruit were 29.50 to $33.47 \mathrm{ml}$ and 1.17 to 1.13 respectively (Kulkarni et al.) Conventional method used for punching Aonla is unhygienic in nature, increase injury probability and Automatic pricking machine is high in cost which is out of reach from small and medium farmer. This paper indicates capability of Machine to prick Aonla to overcome problems like high cost of machine, unhygienic nature, injuries 
of worker. This machine mostly used by small and medium farmers.

\section{Objective}

To design and develop a paddle operated Aonla pricking machine for reducing drudgery and injury to farm women.

\section{MATERIALS AND METHODS}

Fully mature Aonla fruit were harvested from SHUATS orchard and stored in cool place before conducting experiments. All the experiment was conducting at the room temperature at $(27 \pm 2 \mathrm{C})$. All the physical parameters were studied prior to check the machine performance.

Physical parameters of Aonla: Physical parameter of Aonla was obtained from heap of Aonla. 10 Aonla was randomly selected from heap of Aonla then physical parameter like Diameter, Weight and surface area of Aonla.

Diameter of Aonla: Diameter of Aonla was measured by vernier caliper (least count $0.01 \mathrm{~mm}$ ). 10 no of Aonla was randomly selected from heap of Aonla. Aonla has average diameter of $36.8042 .96 \mathrm{~mm}$ (vertical) and 32.38 to 36.72 (horizontal).

Weight of Aonla : Weight of Aonla was measured by weighing machine least count $(0.1 \mathrm{~g})$.

Surface area of Aonla : It is calculated by sphericity.

Sphericity : The sphericity is a measure of shape character compare to a shape of same volume. Assuming the volume of solid is equal to the volume of tri-axial ellipsoid with intercept $a, b, c$ and the diameter of circumscribe sphare is largest intercept of the ellipsoid, the degree of sphericity was calculated as follows:

$$
D S=\frac{\sqrt[3]{a \times b \times c}}{a}(\text { Nitin Kumar et al. })
$$

Surface area of sphere $=4 \times \pi \times r^{2}$

Pricking efficiency: Pricking efficiency was calculated by ratio of pricking surface of Aonla to surface of Aonla.

$$
\text { Pricking efficiency }=\frac{\text { Pricking surface of Anola }}{\text { Surface of Anola }}
$$

Maximum depth of pricking : Maximum depth of pricking is calculated after pricking of Aonla. Aonla was cut by knife and measure the depth of pricking by vernier caliper (least count $0.01 \mathrm{~mm}$ ).

\section{Machine design}

Firstly machine design was developed in mechanical software solid works. The design that was generated in software has an assumed dimension of paddle operated Aonla pricking machine.
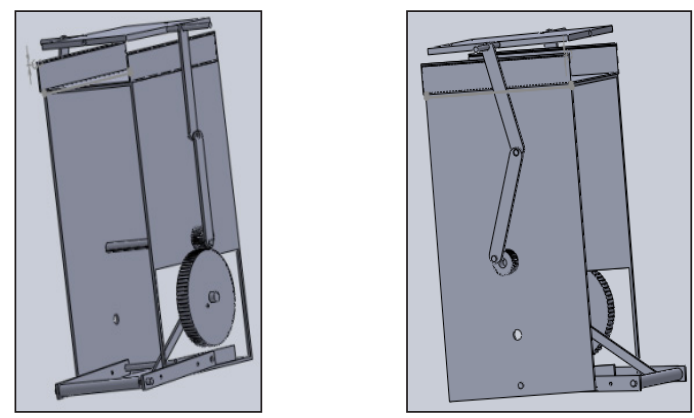

Fig. 1: Right view and Left view Machine design in solid works

\section{Selection pf Machine Part}

\section{Frame}

Frame is the base part of machine. Frame was of load bearing material The material was a mild steel $30 \mathrm{~mm}$ wide and $3 \mathrm{~mm}$ thick L-angle. The angle was cut by cutter in $100 \mathrm{~cm}$ length and welding by electric arc welding. Frame has length breadth and height $60 \times 40 \times 100 \mathrm{~cm}$ respectively.

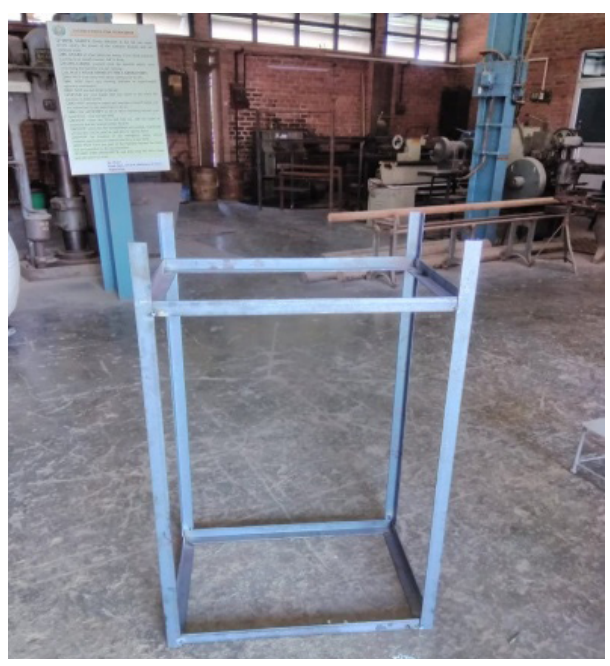

Fig. 2: Frame

SPIKE PLATE: Spike plate has an upward and downward motion to prick Aonla. Spike plate is made up of mild steel. Spike plate has 756 no. of 
holes of $10 \mathrm{~mm}$ diameter with the dimension of plate $40 \times 60 \mathrm{~cm}$.

\section{Needles}

Needles used in machine for pricking Aonla. Needles have $8 \mathrm{~mm}$ maximum cross section area. The plate contains 756 no of needles of stainless steel to prevent corrosion. By remembering the depth of pricking and easy of rolling of Aonla on fruit plate length of needle was 2 inches used.

\section{Seive Plate}

It is also made up of stainless steel. It is used for preventing lifting of Aonla by needles after pricking sieve plate is of $40 \times 60 \mathrm{~cm}$. gap between each rod of steel was $1.5 \mathrm{~cm} .18$ no. of stainless steel rod were connecting in sieve plate.

\section{Gears}

In this machine spur type gears are used. Three gears are used in this machine 2 gears are used for balancing needle plate and remaining one is used to giving reciprocating motion. Gears teeth are move in to and fro motion. Small gears have 50 no. of teethes and large gear have 100 no. of teethes.

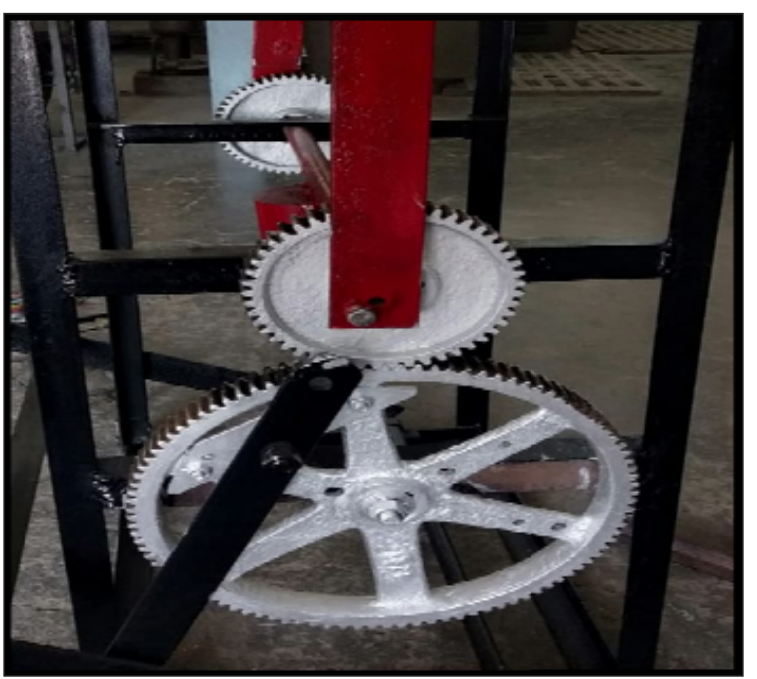

Fig. 3: Gears

\section{Balancing Weight}

It is the heart of machine. it is used to lifting paddle automatically. With the help of balancing weight "machine work in to and fro motion". Balancing weight has $8 \mathrm{~cm}$ cross section area $12 \mathrm{~cm}$ height and $10 \mathrm{~kg}$ weight.

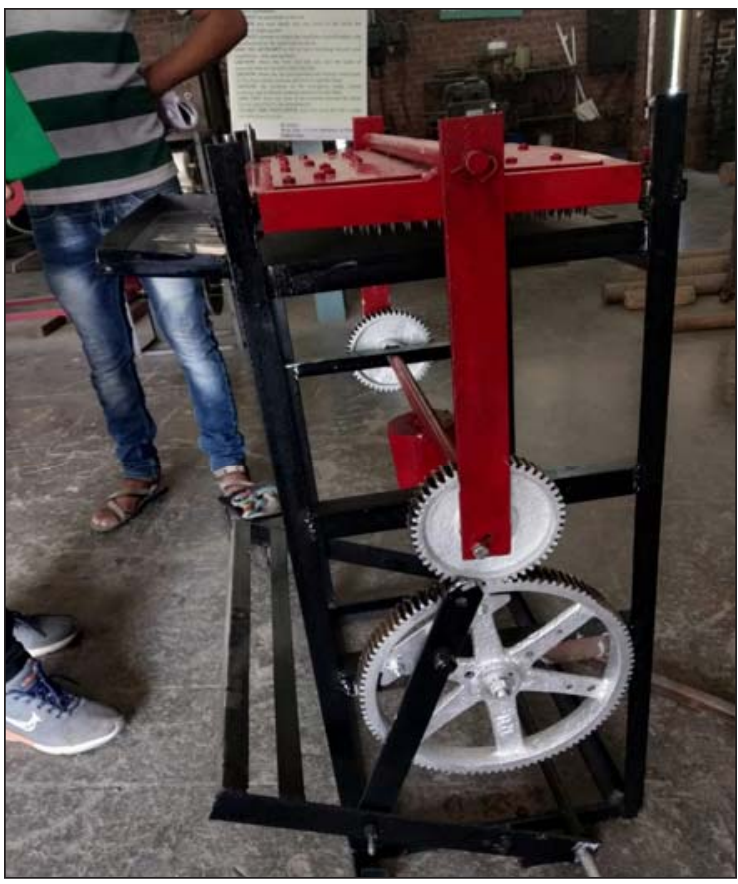

Fig. 4: Aonla pricking machine

\section{RESULTS}

About 10 Aonla fruits of Banarasi variety and average $50 \mathrm{~mm}$ diameter were randomly selected for testing. Depth of pricking of Aonla is measured by vernier caliper. The rate of pricking Aonla was 3-3.5 $\mathrm{q} / \mathrm{hr}$ as shown in table $1 \& 2$.

Table 1: Parameters of Aonla

\begin{tabular}{lllll}
\hline $\begin{array}{l}\text { S1. } \\
\text { No. }\end{array}$ & $\begin{array}{l}\text { Weight in } \\
\text { (gm) }\end{array}$ & $\begin{array}{l}\text { Surface area of } \\
\text { Aonla pricking } \\
\mathbf{( m m}^{\mathbf{2}}\end{array}$ & $\begin{array}{l}\text { Maximum } \\
\text { depth }\end{array}$ & $\begin{array}{l}\text { Pricking } \\
\text { efficiency }\end{array}$ \\
\hline 1 & 27.07 & 4519.85 & 5 & 20.4 \\
2 & 31.60 & 4680.89 & 7 & 19.74 \\
3 & 31.10 & 4603.63 & 7 & 20.07 \\
4 & 31.95 & 5155.47 & 8 & 19.86 \\
5 & 34.04 & 5655.62 & 8 & 19.96 \\
6 & 25.60 & 4439.21 & 8 & 20.8 \\
7 & 26.40 & 4496.06 & 8 & 20.55 \\
8 & 32.26 & 5381.83 & 8 & 20.97 \\
9 & 31.75 & 4666.36 & 8 & 21.9 \\
10 & 23.98 & 4282.41 & 7 & 21.5 \\
\hline
\end{tabular}

Table 2: Testing of machine

\begin{tabular}{llllll}
\hline $\begin{array}{l}\text { Feed } \\
\text { rate } \mathbf{( k g )}\end{array}$ & $\begin{array}{l}\text { Diameter Depth of Pricking } \\
(\mathbf{m m})\end{array}$ & $\begin{array}{l}\text { Output } \\
\text { pricking } \\
(\mathbf{m m})\end{array}$ & $\begin{array}{l}\text { Losses } \\
\text { efficiency } \\
\mathbf{( \% )}\end{array}$ & $\begin{array}{l}\text { capacity } \\
\mathbf{( k g )}\end{array}$ & $\begin{array}{l}\text { Aonla }) \\
\text { (no. of }\end{array}$ \\
\hline 4 & 38 & 5 & 20.45 & 370 & 2 \\
& 40 & 7 & 18.49 & 365 & 3 \\
& 42 & 7.5 & 19.86 & 355 & 5 \\
\hline
\end{tabular}




\begin{tabular}{|c|c|c|c|c|c|}
\hline \multirow[t]{3}{*}{6} & 38 & 6.5 & 20.4 & 340 & 2 \\
\hline & 40 & 7.2 & 19.86 & 342 & 2 \\
\hline & 42 & 7.9 & 19.96 & 340 & 3 \\
\hline \multirow[t]{3}{*}{8} & 38 & 5 & 15.46 & 370 & 5 \\
\hline & 40 & 7.2 & 18.40 & 371 & 6 \\
\hline & 42 & 7.5 & 20.21 & 372 & 5 \\
\hline
\end{tabular}

Output capacity: Output capacity of machine is calculated according to feed rate of Aonla by time. Means Aonla prick in machine per hour is known as output capacity of Aonla pricking machine.

Losses of Aonla: losses of Aonlas are calculated in natural numbers. losses of Aonla was depend on feed rate and size of Aonla.

Table 3 was show pricking efficiency, output capacity, and losses of Aonla by feed rate $4 \mathrm{~kg}, 5 \mathrm{~kg}$, $6 \mathrm{~kg}$ with the diameter of $38,40,42 \mathrm{~mm}$. As we seen that depth of pricking was depend on diameter of Aonla. Means max. Diameter has max. depth and min. diameter has min. depth.

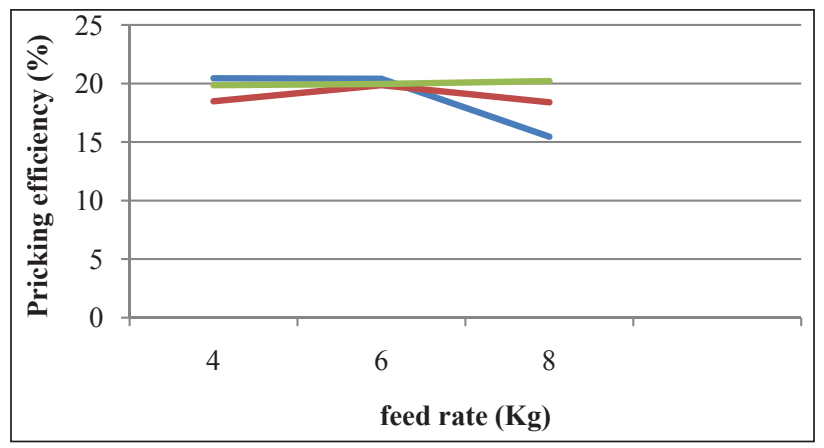

Graph 1: Aonla pricking feed rate

This graph show that the feed rate of Aonla $6 \mathrm{~kg} /$ min was much better for pricking.

\section{REFERENCES}

Bhattacherjee, A.K., Dikshit, A., Kumar, S., Shukla, D.K. and Tandon, D.K. 2013. Quality evaluation in storage of aonla (Emblica officinalis Gaertn.) juice extracted from fruits preserved by steeping in water. International Food Research Journal, 20(4): 1861-1865.

Ganvir Akash, P. and Awate, N.P. 2015. Design E Development of Aonla Fruits Seed Removal E Shredding Machine. IJMETMR.

Ghuge. Kishore V., Kolhe Renuka, T., Borkar Shreya, P., Chaudhari Kalpesh, C. and Dange Swanil, S. 2016. Design and analysis of Amla punching machine. JETIR., 16051260

Goyal, R.K., Patil, R.T., Kingsly, A.R.P., Walia, H. and Kumar Pradeep. 2008. Status of post harvest technology of Aonla in india. American Journal of Food Technology, 3(1): 13-23.

Kumar Nitin, Kumar Arun, Sharma D.K. and Garg M.K. 2014. Performance Evaluation of Power Operated Aonla Pricking Machine Considering Physical and Nutritional Properties Aonla.

Priya, M.D. and Khatkar, B.S. Effect of processing methods on keeping quality of aonla (Emblica officinalis Gaertn.) preserve. International Food Research Journal, 20(2): 617-622.

Rai Arpana, Gandhi Sudesh, Kumar Nitin, Sharma D.K. and Garg M.K. 2012. Ergonomic intervention in Aonla pricking operation during preserve preparation in food processing industries www.researchgate.net/publication/278102378

Verma R.C. and Gupta Ajay. 2003. Effect of pre-treatments on quality of solar-dried amla. Journal of Food Engineering, 65: 397-402.

www.researchgate.net/publication /324890591 